\title{
Assessment of pulmonary changes in the course of systemic lupus erythematosus - application of high resolution computed tomography
}

\author{
Zastosowanie tomografii komputerowej wysokiej rozdzielczości w diagnostyce \\ zmian płucnych u chorych na toczeń rumieniowaty układowy
}

\author{
Sławomir Jeka ${ }^{1}$, Paweł Żuchowski², Marta Dura ${ }^{3}$, Rafał Wojciechowski ${ }^{1}$, Elżbieta Sokólska ${ }^{3}$ \\ ${ }^{1}$ Department of Rheumatology and Connective Tissue Diseases, Dr. J. Biziel's $2^{\text {nd }}$ University Hospital in Bydgoszcz, \\ Collegium Medicum in Bydgoszcz, Nicolaus Copernicus University in Toruń \\ ${ }^{2}$ Independent Section of Scientific Research Coordination and Didactic Activity, Dr. J. Biziel's $2^{\text {nd }}$ University Hospital in Bydgoszcz, \\ Collegium Medicum in Bydgoszcz \\ ${ }^{3}$ Department of Radiology and Diagnostic Imaging, Dr. J. Biziel's $2^{\text {nd }}$ University Hospital in Bydgoszcz, Collegium Medicum \\ in Bydgoszcz, Nicolaus Copernicus University in Toruń
}

Key words: systemic lupus erythematosus, computed tomography, pulmonary changes.

Słowa kluczowe: toczeń rumieniowaty układowy, tomografia komputerowa, zmiany płucne.

\begin{abstract}
Sum mary
Systemic lupus erythematosus (SLE) is an autoimmune disease that leads to a chronic inflammatory process in tissues and organs. The ailments of the respiratory system are dominated by dry or exudative pleurisy. Interstitial changes can occur, and their effects vary depending on their severity. In extreme cases, they may lead to death. The paper presents a description of three SLE patients with different severity of organ changes treated in the Department of Rheumatology. During the process of diagnosis and treatment, among others chest $X$-ray and high resolution computed tomography (HRCT) of the lungs were performed. Based on the chest X-ray results, no interstitial lung changes were detected, whereas based on the HRCT every patient was diagnosed with an interstitial lung process. In the assessment of pulmonary changes in the course of SLE, HRCT allows the diagnosis of organ damage in an early stage and the introduction of appropriate treatment.
\end{abstract}

\section{Introduction}

Systemic lupus erythematosus (SLE) belongs to chronic inflammatory diseases of a mixed etiology. The

\section{Streszczenie}

Toczeń rumieniowaty układowy (TRU) jest chorobą autoimmunologiczną prowadzącą do przewlekłego procesu zapalnego w tkankach i narządach. Wśród objawów ze strony układu oddechowego dominuje suche lub wysiękowe zapalenie opłucnej. Mogą wystąpić również zmiany śródmiąższowe, których skutki są różne w zależności od stopnia ich nasilenia. W skrajnych przypadkach mogą nawet prowadzić do śmierci. W artykule opisano trzy chore na TRU z różnym stopniem zaawansowania zmian narządowych leczone w Klinice Reumatologii. Chore w czasie procesu diagnostyczno-terapeutycznego miały m.in. wykonywane badania rentgenowskie (RTG) klatki piersiowej i tomografię komputerową wysokiej rozdzielczości (HRCT) płuc. Na podstawie wyników badań RTG klatki piersiowej u żadnej z pacjentek nie stwierdzono zmian śródmiąższowych płuc, natomiast w badaniu HRCT odnotowano także zmiany u każdej z badanych kobiet. W ocenie zmian płucnych w przebiegu TRU wykonane badanie HRCT pozwala na rozpoznanie powikłań narządowych we wczesnej fazie i zastosowanie odpowiedniego leczenia.

disease, involving many organs and systems, has an autoimmune background associated with the formation of autoantibodies and immune complexes. The disease has a varied activity, with periods of exacerbations and

Address for correspondence:

Sławomir Jeka, MD, PhD, Department of Rheumatology and Connective Tissue Diseases, Dr. J. Biziel's $2^{\text {nd }}$ University Hospital in Bydgoszcz, Collegium Medicum in Bydgoszcz, Nicolaus Copernicus University in Toruń, Ujejskiego 75, 85-168 Bydgoszcz, e-mail: p.zuchowski81@gmail.com

Submitted: 4.09.2014 
remissions, and chronic inflammation may result in dys function of many organs and systems. The incidence of SLE ranges between 15 and 50 per 100,000 subjects. Systemic lupus erythematosus affects approximately $0.5 \%$ of the Caucasian population, and almost $2 / 3$ of cases develop at the age between 16 and 55 years, mainly among women [1].

Chronic inflammation may involve the skin, musculoskeletal system, kidneys, central nervous system, hematopoietic system, heart, or lungs.

Pleuritis observed in 30-60\% of patients is the most common symptom associated with respiratory system involvement. Lupus pneumonitis is diagnosed significantly more rarely and it has varied clinical manifestations and symptoms observed in imaging tests due to its chronic or acute course [2].

Lung diseases associated with SLE can be divided into two main groups. Acute lupus pneumonitis (ALP) belongs to the first group and it manifests with fever, asthenia, progressive dyspnea, cough, less frequently hemoptysis, often accompanied by other symptoms of exacerbation of the underlying disease. Inflammatory infiltrations in the lungs are present in the pulmonary parenchyma, and there are also alveoli with a typical inflammatory discharge inside as well as infiltration in the pulmonary interstitium which corresponds to acute interstitial pneumonia (AIP). The inflammation observed in the course of AIP can be accompanied by lesions consistent with diffuse alveolar damage (DAD), pleuritis and less frequently diffuse alveolar hemorrhage (DAH), manifesting with cough, hemoptysis, rapidly progressing dyspnea or chest pain. With regard to the differential diagnosis of such various clinical manifestations, one has to take into account antiphospholipid syndrome that may coexist with lupus, as well as systemic vasculitis or acute as well as chronic focal recurrent pulmonary embolism that may lead to interstitial changes combined with progressive fibrosis and pulmonary hypertension. Despite the fact that acute lupus pneumonitis is rarely observed in the course of SLE, its diagnosis based on the clinical picture combined with radiological findings is not as challenging as therapy. High-dose glucocorticosteroids (GS) combined with immunosuppressive agents (cyclophosphamide the most frequently) applied according to different variants of the therapeutic regimen prepared by the National Institute of Health $(\mathrm{NIH})$ are poorly effective, and the disease is associated with a high mortality rate $[3,4]$.

Chronic interstitial pneumonitis combined with interstitial fibrosis of various degree is the second group of lung diseases observed in SLE. In this case, diagnostics is more challenging to clinicians. At the beginning, pulmonary lesions may start to develop without significant clinical symptoms or chest X-ray abnormalities. Non-specific interstitial pneumonia (NSIP) is associated with a good prognosis, and a process of pulmonary fibrosis, which usually progresses slowly, is relatively rarely present. Radiological symptoms associated with SLE are similar to those observed in other rheumatoid diseases. High resolution computed tomography (HRCT) makes it possible to visualize areas with ground-glass opacity of various degree, pleural thickening and/or pleural and pericardial effusion, as well as pulmonary parenchymal consolidations, or even a honeycomb picture. In the case of hemoptysis, which is one of the symptoms of vasculitis and alveolar hemorrhage, a radiological examination may reveal nodules in the middle part of the lobule and lesions with ground-glass opacity.

Appropriate imaging tests are of special importance with regard to the evaluation, making therapeutic decisions or monitoring of inflammation within the lungs. Apart from a classic X-ray, more advanced imaging techniques are used, including ultrasonography (USG) of the pleura, computed tomography $(\mathrm{CT})$ and $\mathrm{HRCT}[3,5,6]$.

High resolution computed tomography is the most precise test among those presented above; however, one of its limitations is associated with patient exposure to ionizing radiation; nonetheless, the exposure dose associated with HRCT is not as high as for example in vascular examinations. High resolution computed tomography is an optimum diagnostic tool to assess pulmonary changes in SLE as it makes it possible to detect lesions significantly more early than can be done with other imaging tests.

\section{Case reports \\ Patient 1}

A 59-year-old female patient, non-smoker, with no history of exposure to pneumotoxic factors, with SLE diagnosed in 2009 (skin lesions - facial erythema and hypersensitivity to sunlight; arthralgia and joint swelling; respiratory symptoms - effort dyspnea, cough; immune disturbances - currently ANA and dsDNA antibodies; and hematological abnormalities - leukopenia). Respiratory complaints (impaired effort tolerance, effort dyspnea, chronic dry cough) were present at the same time that the underlying disease was diagnosed. A physical examination revealed bilateral crepitations in lower fields of the lungs. Interstitial lung disease was confirmed during hospitalization at the Ward of Lung Diseases in July 2009 (limiting restrictive ventilatory constraint, mild, impaired DLCO - 62\%; DLCO - carbon monoxide diffusing capacity). HRCT of the lungs was performed 28 months before a chest $\mathrm{X}$-ray. 


\section{Patient 2}

A 58-year-old female patient with SLE for more than 30 years (diagnosed in November 1979) with typical skin lesions (facial butterfly erythema, décolleté erythema, hypersensitivity to sunlight), articular complaints (pain and swelling of the joints limiting everyday activities), hematological disturbances (recurring thrombocytopenia, leukopenia) and immune disturbances (ANA antibodies with a homogeneous staining pattern and dsDNA antibodies), with no clinical signs of respiratory system involvement. A non-smoker, without a history of exposure to risk factors that might have damaged the lungs. A chest X-ray and HRCT of the lungs were performed with a one-day interval.

\section{Patient 3}

A 43-year-old female patient, with a 10-year history of cigarette smoking (approx. 10 daily), with SLE diagnosed 3 years earlier, with symptoms of renal involvement (proteinuria $<1 \mathrm{~g} / \mathrm{d}$ ), skin lesions (facial erythema and hypersensitivity to sunlight), articular symptoms (pain and swelling of the wrists and small joints in the hands), hematological (recurring thrombocytopenia) and immune disturbances (high levels of dsDNA, ANA with a homogeneous and granular staining pattern). Based on the medical history and physical examination findings, no symptoms of respiratory tract involvement were observed. HRCT of the lungs was performed 18 months before a chest $X$-ray.

\section{Case reports - radiological lesions}

\section{Patient 1}

The HRCT picture presents heterogeneous lesions, and at the same time it is possible to observe coexisting features of early and late stages of fibrosis. Lesions consistent with advanced fibrosis with irregular distribution are predominant in the right lung (Fig. 1). In the parabasal segments of the right lung there are disturbances of the structure of the pulmonary parenchyma with traction bronchiectasis, irregularly distributed reticular lesions and honeycomb areas (Fig. 2). Numerous disseminated small nodular lesions are present in the areas with interstitial lesions. Apart from that, there are bilateral irregular areas with ground-glass opacity consolidations, segmental interlobular septal thickening, fibrotic lesions in the peripheral segments of the lungs, single calcifications and a subpleural streak in the right lung.

A chest X-ray (Fig. 3) did not reveal parenchymal consolidations or focal lesions. The medial shadow was within the norm.
A classic chest $X$-ray did not visualize significant lesions in the lungs, and it was performed more than 2 years after a HRCT that demonstrated significant lesions in this organ even at such an early stage. Typical symptoms of respiratory tract involvement such as effort dyspnea and chronic cough were observed in the patient.

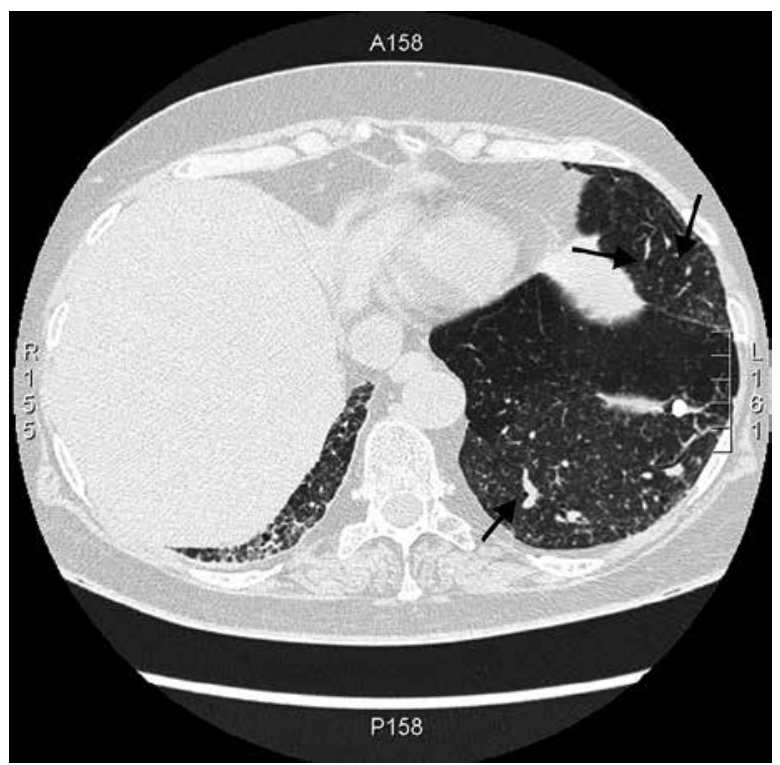

Fig. 1. HRCT image of patient no. 1. Interstitial changes in the form of reticular interstitial opacities and fine nodular changes in the parabasal parts of the lungs. Bronchiectasis due to traction in the left lung (marked by black arrows).

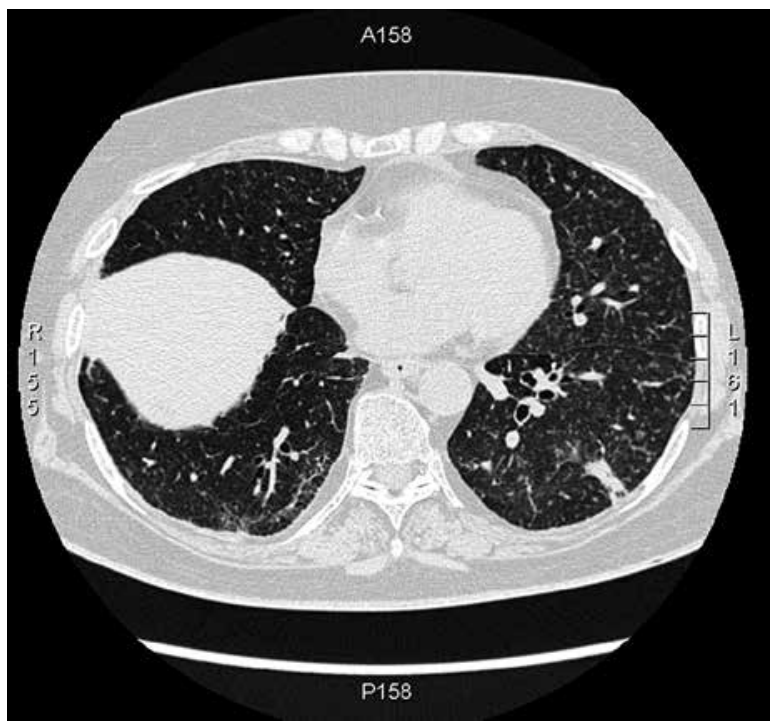

Fig. 2. HRCT image of patient no. 1. Reticular changes and honeycomb opacities. 


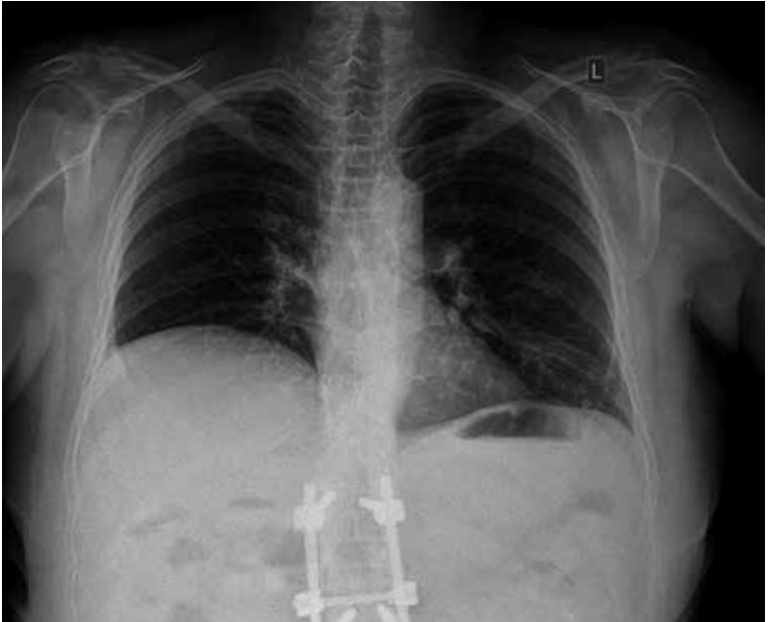

Fig. 3. X-ray image of patient no. 1. No opacities and focal lesions. Heart silhouette is within normal limits. High position of the right dome of the diaphragm.

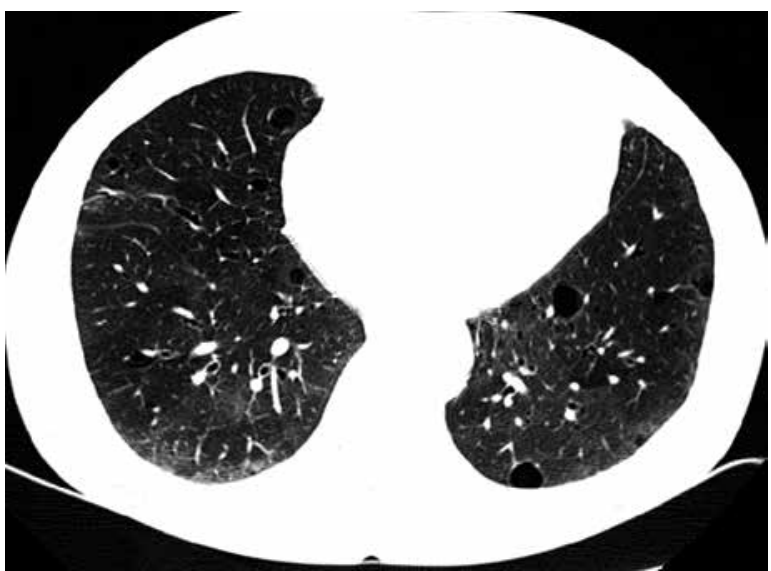

Fig. 4. HRCT image of patient no. 2. Early stage of interstitial lung disease is visualized.

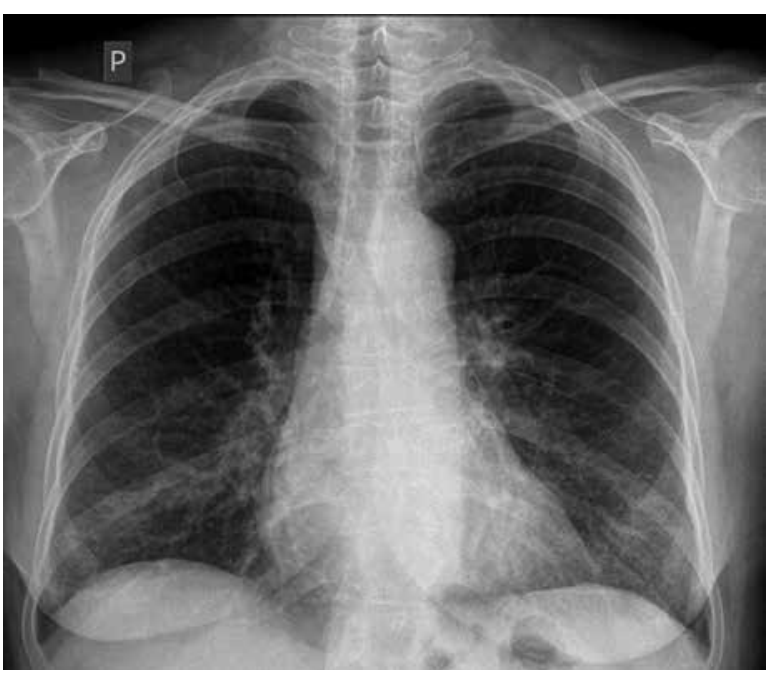

Fig. 5. X-ray image of patient no. 2. Lungs without parenchymal opacities and focal lesions.

\section{Patient 2}

Figure 4 presents lesions consistent with an early stage of interstitial disease visible in HRCT. Irregular areas with ground-glass opacity consolidations and small-reticular interstitial consolidations in the peripheral parts of the lung are predominant. Apart from that, there is bilaterally mild selective interlobular septal thickening, single fibrotic lesions and disseminated cyst-like lesions and emphysematous bullas.

An X-ray (Fig. 5) reveals an intensified pattern of the stroma peribronchially in the inferior lobes of both lungs. Otherwise the lungs are without parenchymal consolidations or focal lesions. The cardiac silhouette is within the norm.

Despite lesions in the lungs that are visible in HRCT and correspond to an early phase of interstitial disease, an X-ray and spirometry with DLCO did not reveal evident abnormalities. At the same time there are not any typical signs of a history of respiratory tract involvement (the patient denies impaired effort tolerance, effort dyspnea or cough), or abnormalities in a physical examination that might suggest lung involvement.

\section{Patient 3}

High resolution computed tomography - in the left lung, mainly subpleurally and in central segments there are areas of small-nodular consolidations and lesions with a tree-in-bud pattern. Additionally, there are spotlike areas with ground-glass opacity consolidations, disseminated cyst-like lesions, single calcifications, interlobular septal thickening and of bronchial wall thickening accompanied by mild traction bronchiectasis (Fig. 6).

The X-ray examination (Fig. 7) was performed in a lying position The lungs are without parenchymal consoli-

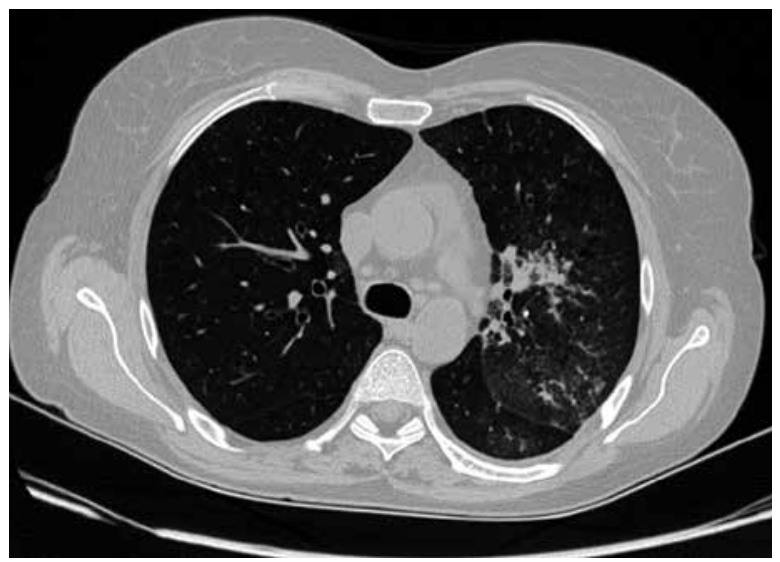

Fig. 6. HRCT image of patient no. 2. Fine nodular changes, tree-in-bud pattern and ground glass pattern, patchy consolidations visualized in the left lung. 


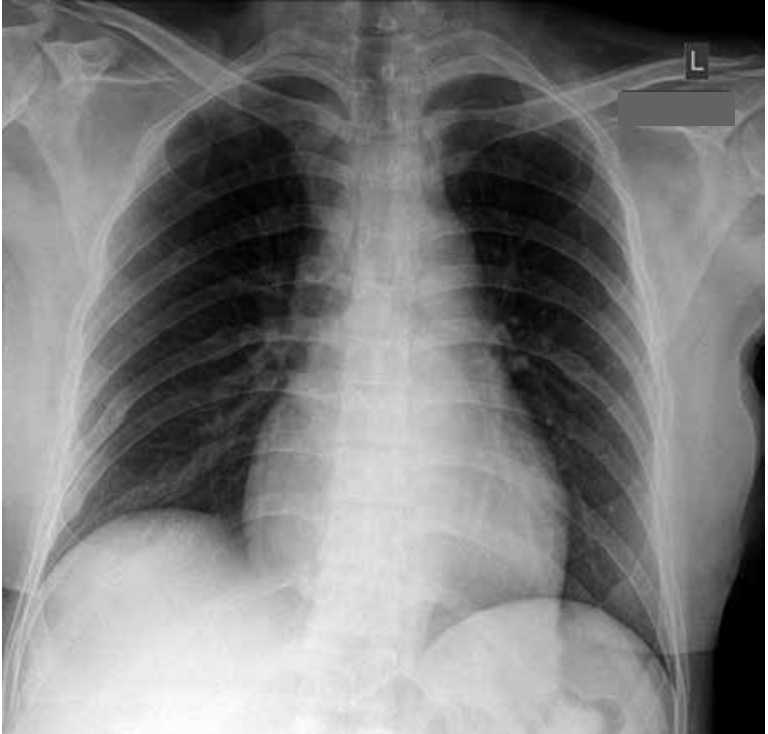

Fig. 7. X-ray image of patient no. 3. Lungs without consolidations or focal lesions. Heart silhouette age and pose adequate.

dations or focal lesions. The middle shadow is appropriate for the age and position. Status post fracture of ribs 7-9 on the right, and rib 6 on the left.

\section{Case discussion}

Symptoms of lung involvement in the course of the underlying disease were present only in the first patient; in the other two there were no abnormalities with regard to the respiratory system functions.

The evaluation of chest $X$-rays performed by two independent radiologists did not reveal pathological lesions in the lungs in those patients. Signs and symptoms observed in the first patient did not correlate with normal findings of a chest X-ray, and this confirms the hypothesis that a classic radiological examination of the respiratory system is of low diagnostic value with regard to chronic interstitial pneumonitis. Radiological findings consistent with NSIP, especially at a less advanced and early stage, cannot be observed in an X-ray examination. NSIP can be diagnosed for certain based on a histopathological evaluation, and not imaging tests. On the other hand, an X-ray makes it possible to diagnose usual interstitial pneumonia (UIP).

Advanced ground-glass opacity lesions are observed in typical X-rays in only $30 \%$ of cases [5]. On the other hand, these lesions are detected by HRCT in as many as $90 \%$ of cases [5]. Therefore HRCT should be considered as an examination of choice both in order to exclude lung involvement and to make appropriate therapeutic decisions, as well as to monitor interstitial pneumonitis.

\section{Conclusions}

1. HRCT performed instead of an X-ray examination in patients with SLE and suspected lung involvement makes it possible to confirm this diagnosis as early as in the asymptomatic period or the period with only a few symptoms.

2. Therefore, it is possible to start appropriate treatment at an early stage of respiratory system involvement, to limit progression of lesions and to alleviate symptoms of interstitial pneumonitis.

3. With regard to diagnostic tests performed in interstitial pneumonitis, $\mathrm{X}$-ray examinations are not necessary as the role of HRCT in diagnostics is conclusive and such examinations should be limited to special cases such as suspected infection, or neoplastic lesions.

4. Dynamics of the clinical picture in the case of acute lupus pneumonitis (ALP) are not associated with many diagnostic problems.

The authors declare no conflict of interest.

\section{References}

1. Szczeklik A. Choroby wewnętrzne. Przyczyny, rozpoznanie, leczenie. Tom II. Wyd. I. Medycyna Praktyczna, Kraków 2005.

2. Kakati S, Doley B, Pal S, Deka UJ. Pulmonary manifestations in systemic lupus erythematosus (SLE) with special reference to HRCT. J Assoc Physicians India 2007; 55: 839-841.

3. Leslie KO, Trahan S, Gruden J. Pulmonary pathology of the rheumatic diseases. Semin Respir Crit Care Med 2007; 28: 369-378.

4. Kur-Zalewska J, Tłustochowicz W. Leczenie tocznia rumieniowatego układowego. Część I. Reumatologia 2012; 50: 383389.

5. Sierakowska M, Sierakowski S, Doroszkiewicz H, et al. Dolegliwości ze strony narządów wewnętrznych $u$ chorych na twardzinę układową w świetle wybranych badań diagnostycznych. Pol Merk Lek 2011; 30: 116-120.

6. Screaton NJ, Miller FN, Patel BD. The clinical impact of high resolution computed tomography in patients with respiratory disease. Eur Radiol 2011; 21: 225-231. 